\title{
An integrated ecosystem approach for assessing the potential role of cultivated bivalve shells as part of the carbon trading system
}

\author{
R. Filgueira ${ }^{1, *}$, C. J. Byron ${ }^{2, * *}$, L. A. Comeau1 ${ }^{1}$, B. Costa-Pierce ${ }^{2}$, P. J. Cranford ${ }^{3}$, \\ J. G. Ferreira ${ }^{4}$, J. Grant ${ }^{5}$, T. Guyondet ${ }^{1}$, H. M. Jansen ${ }^{6,7}$, T. Landry ${ }^{1}$, \\ C. W. McKindsey ${ }^{8}$, J. K. Petersen ${ }^{9}$, G. K. $\operatorname{Reid}^{10,11}$, S. M. C. Robinson ${ }^{11}$, A. Smaal ${ }^{7}$, \\ R. Sonier ${ }^{1}, \varnothing$. Strand $^{6}$, T. Strohmeier ${ }^{6}$ \\ ${ }^{1}$ Department of Fisheries and Oceans, Gulf Fisheries Centre, Science Branch, PO Box 5030, Moncton, \\ New Brunswick E1C 9B6, Canada \\ ${ }^{2}$ Department of Marine Sciences, Marine Science Center, University of New England, Biddeford, Maine 04005, USA \\ ${ }^{3}$ Department of Fisheries and Oceans, Bedford Institute of Oceanography, Dartmouth, NS B2Y 4A2, Canada \\ ${ }^{4}$ Department of Environmental Engineering, Faculty of Sciences and Technology, New University of Lisbon, Qta Torre, \\ 2829-516 Monte de Caparica, Portugal \\ ${ }^{5}$ Department of Oceanography, Dalhousie University, Halifax, Nova Scotia B3H 4R2, Canada \\ ${ }^{6}$ Institute of Marine Research, PO Box 1870 Nordnes, 5817 Bergen, Norway \\ ${ }^{7}$ Institute for Marine Resources and Ecosystem Studies (IMARES), PO Box 77, 4400 AB Yerseke, The Netherlands \\ ${ }^{8}$ Department of Fisheries and Oceans, Maurice-Lamontagne Institute, Ocean and Environmental Sciences Division, \\ PO Box 1000, Mont Joli, Quebec G5H 3Z4, Canada \\ ${ }^{9}$ The Danish Shellfish Centre-DTU Aqua, 7900 Nykøbing Mors, Denmark \\ ${ }^{10}$ Canadian Integrated Multi-Trophic Aquaculture Network (CIMTAN), University of New Brunswick, PO Box 5050, \\ Saint John, New Brunswick E2L 4L5, Canada \\ ${ }^{11}$ Department of Fisheries and Oceans, St. Andrews Biological Station, 531 Brandy Cove Road, St. Andrews, \\ New Brunswick E5B 2L9, Canada
}

\begin{abstract}
The role of bivalve mariculture in the $\mathrm{CO}_{2}$ cycle has been commonly evaluated as the balance between respiration, shell calcium carbonate sequestration and $\mathrm{CO}_{2}$ release during biogenic calcification. However, this approach neglects the ecosystem implications of cultivating bivalves at high densities, e.g. the impact on phytoplankton dynamics and benthic-pelagic coupling, which can significantly contribute to the $\mathrm{CO}_{2}$ cycle. Therefore, an ecosystem approach that accounts for the trophic interactions of bivalve aquaculture, including dissolved and particulate organic and inorganic carbon cycling, is needed to provide a rigorous assessment of the role of bivalve mariculture in the $\mathrm{CO}_{2}$ cycle. On the other hand, the discussion about the inclusion of shells of cultured bivalves into the carbon trading system should be framed within the context of ecosystem goods and services. Humans culture bivalves with the aim of producing food, not sequestering $\mathrm{CO}_{2}$ in their shells, therefore the main ecosystem good provided by bivalve aquaculture is meat production, and shells should be considered as by-products of this human activity. This reasoning provides justification for dividing up respired $\mathrm{CO}_{2}$ between meat and shell when constructing a specific bivalve $\mathrm{CO}_{2}$ budget for potential use of bivalve shells in the carbon trading system. Thus, an integrated ecosystem approach, as well as an understanding of the ecosystems goods and services of bivalve aquaculture, are 2 essential requisites for providing a reliable assessment of the role of bivalve shells in the $\mathrm{CO}_{2}$ cycle.
\end{abstract}

KEY WORDS: Aquaculture $\cdot$ Bivalve $\cdot \mathrm{CO}_{2} \cdot$ Carbon cycling $\cdot$ Carbon trading system

*Corresponding author: ramonf@me.com

${ }^{* *}$ Co-authors after R. Filgueira are listed in alphabetical order
(C) Inter-Research and Fisheries and Oceans Canada 2015 . www.int-res.com 


\section{Bivalve mariculture and the carbon cycle}

The role of bivalve mariculture in the carbon cycle is starting to generate attention in the scientific literature (e.g. Hicky 2009, Tang et al. 2011, Munari et al. 2013, Waldbusser et al. 2013), given the need to explore potential ways of stabilizing atmospheric $\mathrm{CO}_{2}$ to control climate change (Le Quéré et al. 2009) while meeting the accelerating global demands for seafood. The role of calcifying marine organisms such as bivalves in the $\mathrm{CO}_{2}$ budget has been commonly studied by measuring the balance between respiration and biogenic calcification (e.g. Chauvaud et al. 2003, Martin et al. 2006). The catabolism of ingested organic matter following:

$$
\mathrm{CH}_{2} \mathrm{O}+\mathrm{O}_{2} \rightarrow \mathrm{CO}_{2}+\mathrm{H}_{2} \mathrm{O}
$$

and the formation of calcium carbonate $\left(\mathrm{CaCO}_{3}\right)$ by biogenic calcification:

$$
\mathrm{Ca}^{2+} 2 \mathrm{HCO}_{3}{ }^{-} \leftrightarrow \mathrm{CaCO}_{3}+\mathrm{CO}_{2}+\mathrm{H}_{2} \mathrm{O}
$$

both imply $\mathrm{CO}_{2}$ release. These processes depend on $\mathrm{pH}$, alkalinity, salinity and temperature (Millero 1995, Lerman \& Mackenzie 2005, Dickson 2010, Mackenzie \& Andersson 2013) and induce shifts in the seawater carbonate system:

$\mathrm{CO}_{2}+\mathrm{H}_{2} \mathrm{O} \leftrightarrow \mathrm{H}_{2} \mathrm{CO}_{3} \leftrightarrow \mathrm{H}^{+}+\mathrm{HCO}_{3}^{-} \leftrightarrow 2 \mathrm{H}^{+}+\mathrm{CO}_{3}{ }^{2-}$

The balance between respiration, shell calcium carbonate sequestration and $\mathrm{CO}_{2}$ release in biogenic calcification has been used to suggest the role of several invasive molluscs as $\mathrm{CO}_{2}$ generators (e.g. Chauvaud et al. 2003, Martin et al. 2006, Mistri \& Munari 2013). Recently, Munari et al. (2013) applied the same concept (Fig. 1) to conclude that mussel farming is a significant additional source of $\mathrm{CO}_{2}$ to seawater, and thus shell formation cannot be part of the carbon trading system.

We are concerned about the application of this approach to cultured populations, which are farmed and harvested with the aim of providing a key coastal ecosystem service, i.e. high-quality protein for human consumption. Specifically, there are 2 aspects that should be included in the discussion to evaluate the inclusion (or not) of shells from cultured bivalves in carbon trading systems: (1) an ecosystem approach, considering the effects of cultured populations and not the budget of a single individual, is needed to assess the bivalve's role in the carbon cycle, and (2) this holistic approach should also consider that bivalves are a combination of tissue and shell, both of which require energy expenditure for maintenance and growth; consequently, the $\mathrm{CO}_{2}$ released through respiration should be proportionally split between both components. Therefore, it is critical that any assessment of the inclusion of bivalve shells in carbon trading systems, which requires a specific $\mathrm{CO}_{2}$ budget for shells and not for the whole organism, also considers the division of $\mathrm{CO}_{2}$ fluxes between shell and tissue. Finally, indirect effects of bivalve culture on the ecosystem, such as mitigation of eutrophication and enhancement of primary production through increased water clarity and nutrient turnover, should be also considered, given their potential effects on the $\mathrm{CO}_{2}$ cycle.

\section{Ecosystem approach: the need for an integral analysis}

The cultivation of bivalves at high densities can exert a significant effect on flows of matter and energy in coastal marine ecosystems (Dowd 2003) (Fig. 2). The most obvious effect of introducing a large biomass of filter-feeders is related to phytoplankton. Bivalve filtration activity may exert a topdown control of phytoplankton populations (Dame 1996, Dame \& Prins 1998, Escaravage \& Prins 2002, Newell 2004, Prins \& Escaravage 2005, Petersen et al. 2008), to the extent that phytoplankton depletion can compromise bivalve performance when cultured at high densities (Bacher et al. 2003, Ferreira et al. 2007, Duarte et al. 2008, Rosland et al. 2011) and under certain hydrodynamic conditions (Aure et al. 2007, Saurel et al. 2013). During the feeding process, phytoplankton and particulate organic matter are consolidated into pseudofaeces (uningested), and faeces (undigested), which sink to the bottom and redirect part of the pelagic energy flow towards benthic food webs (Newell 2004). Remineralization of nutrients in pseudofaeces and faeces in the water column and mostly in the benthos (Grant et al. 1995,

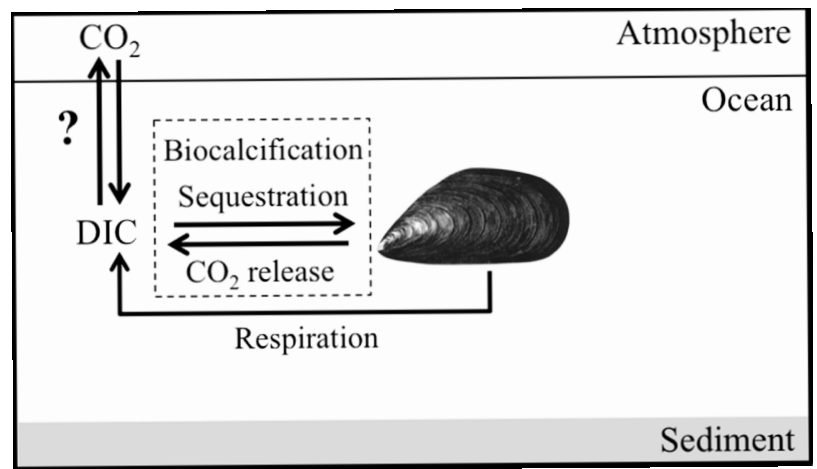

Fig. 1. Chemical approach to the inorganic carbon cycle in mussel culture. DIC: dissolved inorganic carbon 


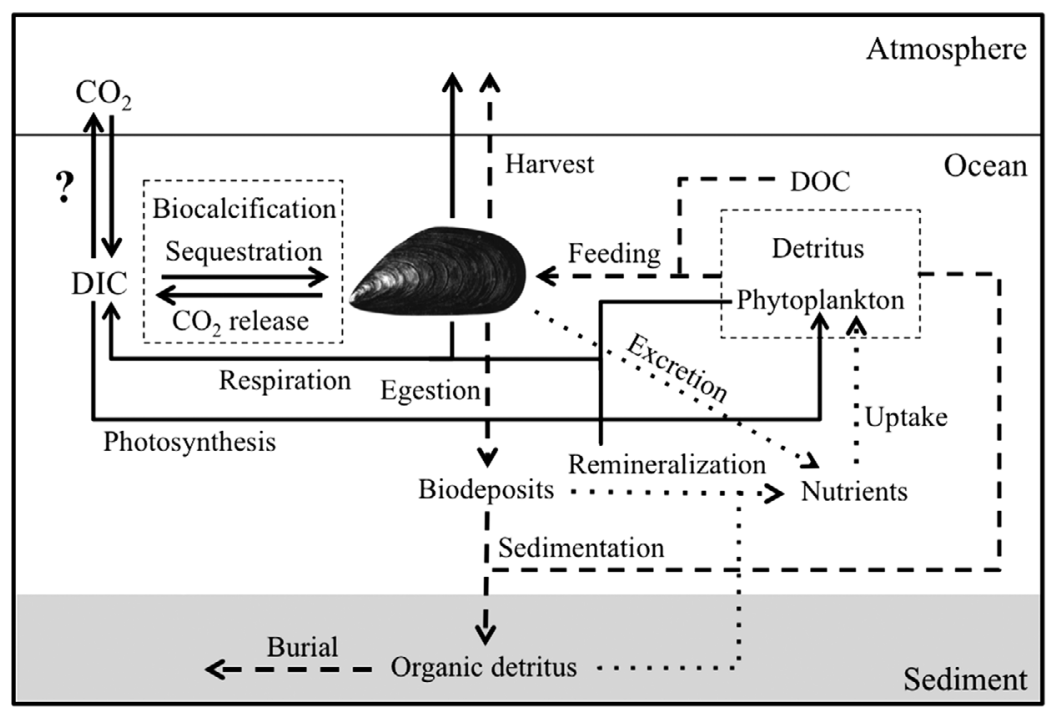

Fig. 2. Ecosystem approach to carbon cycling (continuous and dashed lines for inorganic and organic carbon, respectively) and feedbacks of mussel aquaculture on the pool of inorganic nutrients (dotted line). DOC (DIC): dissolved (in)organic carbon

Newell 2004, Carlsson et al. 2010, Jansen et al. 2012), as well as bivalve ammonia excretion, can accelerate the nitrogen cycle (Dame et al. 1991, Cranford et al. 2007). The ecological significance of nutrient regeneration consists of a relaxation of nutrient limitation for phytoplankton, which may result in enhanced primary production (Smaal 1991, Prins et al. 1995). Therefore, cultured shellfish can also exert a bottomup nutrient control on phytoplankton populations (Ogilvie et al. 2000, Cranford et al. 2007, Trottet et al. 2008, Froján et al. 2014), which is considered to be an important feedback of bivalves on their own food source (Smaal et al. 2001). The remineralization of pseudofaeces and faeces also releases $\mathrm{CO}_{2}$ and alters benthic-pelagic coupling, processes that should be accounted for in an ecosystem approach.

The interactions between bivalves, carbon flow and nutrient cycling are complex, and understanding the magnitude of direct and feedback interactions between cultured populations and phytoplankton, particulate organic carbon, dissolved organic carbon and nutrient dynamics is crucial for understanding the inorganic carbon budget. As mentioned above, bivalve grazing can have a top-down effect on phytoplankton growth and production, particularly in light-limited systems, by decreasing turbidity, continuously grazing larger algal cells, and facilitating a shift to faster growing algal species (Prins et al. 1995). In nutrient-limited systems, bivalves exert a bottomup control on the phytoplankton by retaining nutrients in the system and increasing the rate of nutrient cycling and consequently nutrient availability (Dame et al. 1991, Smaal 1991). For example, mesocosm studies with the clam Mercenaria mercenaria show that a relatively low abundance of clams can double primary production and alter phytoplankton community structure (Doering \& Oviatt 1986, Doering et al. 1989). The progressive increase of bivalve retention efficiency from small to large particles (Strohmeier et al. 2012) can also result in increased picophytoplankton abundance (Olsson et al. 1992, Vaquer et al. 1996, Cranford et al. 2008, Froján et al. 2014) with related effects on the local rate of carbon uptake by phytoplankton. As bivalve populations increase to high levels, a point will eventually be reached where grazing on phytoplankton begins to reduce primary production, and consequently $\mathrm{CO}_{2}$ uptake by phytoplankton (Smaal et al. 2013). In addition, local ecosystem characteristics can exert critical effects on carbon budgets. For example, in deep fjord-type systems, the sedimentation of aquaculture wastes would transfer carbon to deep waters, potentially reaching the sediment (Sepúlveda et al. 2005), which can be considered as a carbon storage compartment. On the other hand, vertical fluxes of organic matter towards the seafloor in shallow environments may, depending on bivalve stocking and hydrological conditions, significantly affect habitat characteristics and infaunal communities in the vicinity of the farm (e.g. Mirto et al. 2000, Hargrave et al. 2008, Cranford et al. 2009, Guyondet et al. in press), concomitantly affecting benthic-pelagic coupling and the $\mathrm{CO}_{2}$ cycle. This local variability is also reflected in the differential fluxes of $\mathrm{CO}_{2}$ between estuaries and the atmosphere depending on estuarine topography, hydrodynamics, terrestrial organic carbon budget and magnitude, and stoichiometry of nutrient inputs (Laruelle et al. 2010, Bauer et al. 2013). In addition, bivalve anaerobic metabolism (de Zwaan \& Wijsman 1976), which depends on local conditions and/or culture technique (intertidal vs. subtidal), may also affect $\mathrm{CO}_{2}$ fluxes. Therefore, a rigorous assessment of the role of bivalve aquaculture in the $\mathrm{CO}_{2}$ budget should be based on an ecosystem approach that accounts for the complex trophic interactions involving dissolved and particulate organic and inorganic carbon cycling, as well as local and seasonal variability. 


\section{Ecosystem services: attributing respired $\mathrm{CO}_{2}$ to tissue or shell}

According to the most recent predictions, the world's current human population of 7.2 billion is projected to reach 9.6 billion by 2050 (UN 2013). Constraints on the availability of freshwater and land plants and animals to feed this projected population increase can be overcome by enhancing the contribution of the ocean to food production (Duarte et al. 2009). This contribution must be achieved by (1) the recovery of wild fisheries and adjusting the global fishing effort to sustainable levels (Pauly et al. 2002), and (2) farming the ocean while maintaining environmental health and sustainability (Marra 2005, Byron \& Costa-Pierce 2013). The need for supplemental feeds to grow farmed species is one of the major constraints to aquaculture development (FAO 2012), and one of the challenges to improving aquaculture sustainability (Naylor et al. 2000). However, one-third of the world's farmed seafood harvested from animals in 2010 was achieved without the use of feed, through the production of animals from the second trophic level: bivalves (14.2 million tonnes, $23.6 \%$ of world aquaculture production) and filterfeeding carp (9.6 million tonnes) (FAO 2012). In detail, $89 \%$ of global production of marine bivalves (clams, cockles, mussels, oysters and scallops) came from aquaculture in 2012 (www.fao.org/fishery/ statistics/en). Consequently, the main ecosystem good provided by shellfish aquaculture is meat production, and shells should be considered by-products of this human activity. Therefore, it is important to independently quantify the role of tissue and shell in the $\mathrm{CO}_{2}$ cycle.

Most of the energy consumed by bivalves is invested in maintenance, tissue growth, and reproduction rather than shell growth, the energetic cost of which is limited to producing the conchiolin matrix that allows precipitation and shell formation. There are not strong conclusions in the literature regarding the fraction of total energy that is invested in this matrix, in part because any estimation is highly dependent on environmental conditions such as salinity and temperature. Hawkins \& Bayne (1992) estimated that Mytilus edulis could spend more than $20 \%$ of the energy that is available for growth (Scope For Growth; Winberg 1960) on shell formation. This matches the calculations of Duarte et al. (2010), who estimated that Mytilus galloprovincialis could invest an average of 20 to $28 \%$ of the energy that is available for growth in shell formation. In addition, mussels invest differing amounts of energy into shell for- mation in different habitats (Rodhouse et al. 1984). In intertidal and bottom culture, mussels invest more of the energy that is available for growth towards producing relatively thick shells compared to mussels cultivated in suspended structures, which could be related to feeding conditions (Aldrich \& Crowley 1986), hydrodynamics (Steffani \& Branch 2003) and predation pressure (Lowen et al. 2013). As explained above, in the same way that not all the energy consumed by mussels is used for shell formation, not all the $\mathrm{CO}_{2}$ released through respiration should be attributed to shell formation. It is critical to split this $\mathrm{CO}_{2}$ flux between tissue and shell, because the ultimate goal is to determine the potential inclusion of shells rather than whole cultured individuals in the carbon trading system. This reasoning is based on the assumption that humans culture bivalves with the aim of producing food, not sequestering $\mathrm{CO}_{2}$.

In addition to food production, we cannot ignore other ecosystem services provided by farmed bivalves, beyond the discussion of carbon credits. One of the most important is the regulation of nutrient levels in coastal areas. Bivalves can be farmed in hyper-eutrophic coastal waters, which are prone to intense and harmful phytoplankton blooms. Feedbacks brought about by the grazing activity of farmed bivalves may reduce the intensity and duration of blooms, controlling the nitrogen cycle. Thus, bivalves have been suggested as a mitigation tool for coastal eutrophication (Rice 2001, Lindahl 2011, Petersen et al. 2014, Guyondet et al. in press; but see Cranford et al. 2007). Bivalve farming also plays an important role in benthic restoration (Dumbauld et al. 2009). Overall, $85 \%$ of oyster reefs have been lost globally (Beck et al. 2011), and dredging natural populations of mussels is still an ongoing fishery that, as with all dredging activities, may cause harmful impacts on benthic environments (e.g. Jennings \& Kaiser 1998). Bivalve aquaculture can mitigate the pressure on these natural populations (Carranza et al. 2009, Dolmer et al. 2012), but may also represent a form of restoration of ecosystem services previously provided by overfished wild populations. Although shading from farming structures at the local scale can reduce light availability and consequently primary productivity (Skinner et al. 2014, M. Froján et al. unpubl. data), bivalve filtration activity can increase water clarity at the ecosystem level. The increase in light penetration and/or sediment nutrient enrichment promoted by cultured bivalves can also enhance the productivity of seagrass in shallow coastal ecosystems (Peterson \& Heck 2001, Carroll et al. 2008), which may become an important carbon sink 
(Duarte et al. 2013). A recent study conducted in Atlantic Canada showed a positive relationship between farmed oyster biomass and eelgrass, Zostera marina, biomass (A. Locke pers. comm.). The restoration of these services, e.g. water clarity and habitat, may also have effects on the $\mathrm{CO}_{2}$ cycle. Another effect on habitat is related to the deployment of 3-dimensional physical structures in the ocean, which can provide refuge from predators and/or provide food sources for different species (McKindsey et al. 2011), ultimately altering species assemblages (Gibbs 2004), which can impact $\mathrm{CO}_{2}$ fluxes. Therefore, the contribution of shellfish aquaculture to the $\mathrm{CO}_{2}$ cycle and the associated implications on carbon trading systems must be viewed from a broad perspective, without neglecting to account for the provision of other ecosystem services. In fact, a comprehensive approach to the $\mathrm{CO}_{2}$ budget must also include a lifecycle analysis of the commercialized product, as has been done for terrestrial farming (e.g. Smith et al. 2008, Garnett 2009), but that is beyond the scope of this study.

In conclusion, the balance between respiration, shell calcium carbonate sequestration and $\mathrm{CO}_{2}$ release in biogenic calcification provides the most significant fluxes of the $\mathrm{CO}_{2}$ budget in calcifying marine organisms from a chemical standpoint. Nevertheless, a comprehensive analysis of all forms of carbon, as well as significant ecological relationships, feedbacks, and habitats, are required to rigorously quantify the role of cultured bivalves in the $\mathrm{CO}_{2}$ budget of coastal ecosystems. In addition to the need for an ecosystem approach, it is also important to understand the main role of shellfish aquaculture as providing food, i.e. a source of high-quality protein for human consumption. In this comment, we have not attempted to quantify the net contribution of bivalve aquaculture as a source or sink of $\mathrm{CO}_{2}$, a determination that would be highly dependent on seasonality and local characteristics such as farming practices, temperature, phytoplankton populations, nutrients, and potential ecological feedbacks. On the contrary, we wish to highlight the need for an ecosystem approach to quantify the role of bivalve aquaculture in the $\mathrm{CO}_{2}$ budget and, perhaps even more importantly, the need to understand that bivalve shells and not the whole bivalve (tissue and shell) are the potential product to be included in the carbon trading system. Accordingly, given that a specific $\mathrm{CO}_{2}$ budget for shells rather than for the whole organism is required to evaluate the potential inclusion of shells in the carbon trading system, the $\mathrm{CO}_{2}$ released in respiration for the whole individual (Eq. 1) must be proportion- ally split between tissue and shell to construct this specific $\mathrm{CO}_{2}$ budget for shells. Thus, an integrated ecosystem approach as well as an understanding of bivalves as a combination of tissue and shell are 2 essential requisites for providing a reliable assessment of the potential of bivalve shells as part of the carbon trading system.

Acknowledgements. R.F. is sincerely grateful to Marcel Fréchette, Carmen G. Castro and Fred T. Mackenzie for their valuable feedback in early stages of this communication. We also thank the 3 anonymous reviewers for their constructive comments.

\section{LITERATURE CITED}

Aldrich JC, Crowley M (1986) Condition and variability in Mytilus edulis (L.) from different habitats in Ireland. Aquaculture 52:273-286

Aure J, Strohmeier T, Strand Ø (2007) Modelling current speed and carrying capacity in long-line blue mussel (Mytilus edulis) farms. Aquacult Res 38:304-312

Bacher C, Grant J, Hawkins A, Fang J, Zhu P, Duarte P (2003) Modeling the effect of food depletion on scallop growth in Sungo Bay (China). Aquat Living Resour 16: $10-24$

- Bauer JE, Cai WJ, Raymon PA, Bianchi TS, Hopkinson CS, Regnier PAG (2013) The changing carbon cycle of the coastal ocean. Nature 504:61-70

Beck MW, Brumbaugh RD, Airoldi L, Carranza A and others (2011) Oyster reefs at risk and recommendations for conservation, restoration, and management. Bioscience 61: 107-116

Byron CJ, Costa-Pierce BA (2013) Carrying capacity tools for use in the implementation of an ecosystems approach to aquaculture. In: Ross LG, Telfer TC, Falconer L, Soto D, Aguilar-Manjarrez J (eds) Site selection and carrying capacities for inland and coastal aquaculture. FAO Fisheries and Aquaculture Proceedings No. 21, FAO, Rome, p 87-102

Carlsson MS, Glud RN, Petersen JK (2010) Degradation of mussel (Mytilus edulis) fecal pellets released from hanging long-lines upon sinking and after settling at the sediment. Can J Fish Aquat Sci 67:1376-1387

Carranza A, Defeo O, Beck M, Castilla JC (2009) Linking fisheries management and conservation in bioengineering species: the case of South American mussels (Mytilidae). Rev Fish Biol Fish 19:349-366

Carroll J, Gobler CJ, Peterson BJ (2008) Resource-restricted growth of eelgrass in New York estuaries: light limitation, and alleviation of nutrients stress by hard clams. Mar Ecol Prog Ser 369:51-62

> Chauvaud L, Thompson JK, Cloern JE, Thouzeau G (2003) Clams as $\mathrm{CO}_{2}$ generators: the Potamocorbula amurensis example in San Francisco Bay. Limnol Oceanogr 48: 2086-2092

> Cranford PJ, Strain PM, Dowd M, Hargrave BT, Grant J, Archambault MC (2007) Influence of mussel aquaculture on nitrogen dynamics in a nutrient enriched coastal embayment. Mar Ecol Prog Ser 347:61-78

Cranford PJ, Li W, Strand Ø, Strohmeier T (2008) Phytoplankton depletion by mussel aquaculture: high resolu- 
tion mapping, ecosystem modeling and potential indicators of ecological carrying capacity. ICES CM 2008/H: 12, International Council for the Exploration of the Sea, Copenhagen. www.ices.dk/sites/pub/CM\%20Doccuments/ CM-2008/H/H1208.pdf

Cranford PJ, Hargrave BT, Doucette LI (2009) Benthic organic enrichment from suspended mussel (Mytilus edulis) culture in Prince Edward Island, Canada. Aquaculture 292:189-196

Dame RF (1996) Ecology of marine bivalves: an ecosystem approach. CRC Press, Boca Raton, FL

$>$ Dame RF, Prins TC (1998) Bivalve carrying capacity in coastal ecosystems. Aquat Ecol 31:409-421

> Dame R, Dankers N, Prins T, Jongsma H, Smaal A (1991) The influence of mussel beds on nutrients in the western Wadden Sea and eastern Scheldt Estuaries. Estuaries 14: 130-138

de Zwaan A, Wijsman TCM (1976) Anaerobic metabolism in Bivalvia (Mollusca): characteristics of anaerobic metabolism. Comp Biochem Physiol B 54:313-324

Dickson AG (2010) The carbon dioxide system in seawater: equilibrium chemistry and measurements. In: Riebesell U, Fabry VJ, Hansson L, Gattuso JP (eds) Guide to best practices for ocean acidification research and data reporting. Publications Office of the European Union, Luxembourg, p 17-52

$>$ Doering PH, Oviatt CA (1986) Application of filtration rate models to field populations of bivalves: an assessment using experimental mesocosms. Mar Ecol Prog Ser 31: 265-275

> Doering PH, Oviatt CA, Beatty LL, Banzon VF and others (1989) Structure and function in a model coastal ecosystem: silicon, the benthos and eutrophication. Mar Ecol Prog Ser 52:287-299

> Dolmer P, Christesen HT, Hansen BW, Vismann B (2012) Area-intensive bottom culture of blue mussels Mytilus edulis in a micro-tidal estuary. Aquacult Environ Interact 3:81-91

> Dowd M (2003) Seston dynamics in a tidal inlet with shellfish aquaculture: a model study using tracer equations. Estuar Coast Shelf Sci 57:523-537

> Duarte O, Labarta U, Fernández-Reiriz MJ (2008) Modelling local food depletion effects in mussel rafts of Galician Rias. Aquaculture 274:300-312

> Duarte CM, Conley DJ, Carstensen J, Sánchez-Camacho M (2009) Return to Neverland: shifting baselines affect eutrophication restoration targets. Estuar Coast 32: 29-36

Duarte P, Fernández-Reiriz MJ, Filgueira R, Labarta U (2010) Modelling mussel growth in ecosystems with low suspended matter loads. J Sea Res 64:273-286

> Duarte CM, Sintes T, Marbà N (2013) Assessing the $\mathrm{CO}_{2}$ capture potential of seagrass restoration projects. J Appl Ecol 50:1341-1349

> Dumbauld BR, Ruesink JL, Rumrill SS (2009) The ecological role of bivalve shellfish aquaculture in the estuarine environment: a review with application to oyster and clam culture in West Coast (USA) estuaries. Aquaculture 290:196-223

> Escaravage V, Prins TC (2002) Silicate availability, vertical mixing and grazing control of phytoplankton blooms in mesocosms. Hydrobiologia 484:33-48

FAO (2012) The state of world fisheries and aquaculture. Food and Agriculture Organization of the United Nations, Rome
Ferreira JG, Hawkins AJS, Bricker SB (2007) Management of productivity, environmental effects and profitability of shellfish aquaculture - the Farm Aquaculture Resource Management (FARM) model. Aquaculture 264:160-174

> Froján M, Arbones B, Zúñiga D, Castro CG, Figueiras FG (2014) Microbial plankton community in the Ría de Vigo (NW Iberian upwelling system): impact of the culture of Mytilus galloprovincialis. Mar Ecol Prog Ser 498:43-54

> Garnett T (2009) Livestock-related greenhouse gas emissions: impacts and options for policy makers. Environ Sci Policy 12:491-503

Gibbs MT (2004) Interactions between bivalve shellfish farms and fishery resources. Aquaculture 240:267-296

Grant J, Hatcher A, Scott DB, Pocklington P, Schafer CT, Honig C (1995) A multidisciplinary approach to evaluating benthic impacts of shellfish aquaculture. Estuaries 18:124-144

Guyondet T, Comeau LA, Bacher C, Grant J, Rosland R, Sonier R, Filgueira R (in press) Climate change increases carrying capacity in a coastal embayment dedicated to shellfish aquaculture. Estuar Coast

- Hargrave BT, Doucette LI, Cranford PJ, Law BA, Milligan TG (2008) Influence of mussel aquaculture on sediment organic enrichment in a nutrient-rich coastal embayment. Mar Ecol Prog Ser 365:137-149

Hawkins AJS, Bayne BL (1992) Physiological interrelations, and the regulation of production. In: Gosling EG (ed) The mussel Mytilus: ecology, physiology, genetics and culture. Elsevier, Amsterdam, p 171-222

Hicky JP (2009) Carbon sequestration potential of shellfish. www.thefishsite.com/articles/615/carbon-sequestrationpotential-of-shellfish

$>$ Jansen HM, Verdegem MCJ, Strand $\varnothing$, Smaal AC (2012) Seasonal variation in mineralization rates (C-N-P-Si) of mussel Mytilus edulis biodeposits. Mar Biol 159: 1567-1580

Jennings S, Kaiser MP (1998) The effects of fishing on marine ecosystems. Adv Mar Biol 34:201-352

Laruelle GG, Dürr HH, Slomp CP, Borges AV (2010) Evaluation of sinks and sources of $\mathrm{CO}_{2}$ in the global coastal ocean using a spatially-explicit typology of estuaries and continental shelves. Geophys Res Lett 37:L15607, doi: 10.1029/2010GL043691

Le Quéré C, Raupach MR, Canadell JG, Marland G and others (2009) Trends in the sources and sinks of carbon dioxide. Nat Geosci 2:831-836

> Lerman A, Mackenzie FT (2005) $\mathrm{CO}_{2}$ air-sea exchange due to calcium carbonate and organic matter storage, and its implications for the global carbon cycle. Aquat Geochem 11:345-390

Lindahl O (2011) Mussel farming as a tool for re-eutrophication of coastal waters: experiences from Sweden. In: Shumway SE (ed) Shellfish aquaculture and the environment. Wiley-Blackwell, Chichester, p 217-237

Lowen JB, Innes DJ, Thomson RJ (2013) Predator-induced defenses differ between sympatric Mytilus edulis and $M$. trossulus. Mar Ecol Prog Ser 475:135-143

> Mackenzie FT, Andersson AJ (2013) The marine carbon system and ocean acidification during Phanerozoic time. Geochem Perspec 2:1-227

> Marra J (2005) When will we tame the oceans? Nature 436: 175-176

> Martin S, Thouzeau G, Chauvaud L, Jean F, Guérin L, Clavier J (2006) Respiration, calcification, and excretion of the invasive slipper limpet, Crepidula fornicata L.: 
implications for carbon, carbonate, and nitrogen fluxes in affected areas. Limnol Oceanogr 51:1996-2007

McKindsey CW, Archambault P, Callier MD, Olivier F (2011) Influence of suspended and off-bottom mussel culture on the sea bottom and benthic habitats: a review. Can J Zool 89:622-646

Millero FJ (1995) Thermodynamics of the carbon dioxide system in the oceans. Geochim Cosmochim Acta 59: 661-677

> Mirto S, La Rosa T, Danovaro R, Mazzola A (2000) Microbial and meiofaunal response to intensive mussel-farm biodeposition in coastal sediments of the western Mediterranean. Mar Pollut Bull 40:244-252

Mistri M, Munari C (2013) The invasive bag mussel Arcuatula senhousia is a $\mathrm{CO}_{2}$ generator in near-shore ecosystems. J Exp Mar Biol Ecol 440:164-168

- Munari C, Rossetti E, Mistri M (2013) Shell formation in cultivated bivalves cannot be part of carbon trading systems: a study case with Mytilus galloprovincialis. Mar Environ Res 92:264-267

Naylor RL, Goldburg RJ, Primavera JH, Kautsky N and others (2000) Effect of aquaculture on world fish supplies. Nature 405:1017-1024

Newell RIE (2004) Ecosystem influences of natural and cultivated populations of suspension-feeding bivalve molluscs: a review. J Shellfish Res 23:51-61

Ogilvie SC, Ross AH, Schiel DR (2000) Phytoplankton biomass associated with mussel farms in Beatrix Bay, New Zealand. Aquaculture 181:71-80

Olsson P, Graneli E, Carlsson P, Abreu P (1992) Structure of a post spring phytoplankton community by manipulation of trophic interactions. J Exp Mar Biol Ecol 158:249-266

Pauly D, Christensen V, Guénette S, Pitcher TJ and others (2002) Towards sustainability in world fisheries. Nature 418:689-695

> Petersen JK, Hansen JW, Laursen MB, Clausen P, Carstensen J, Conley DJ (2008) Regime shift in a coastal marine ecosystem. Ecol Appl 18:497-510

Petersen JK, Hasler B, Timmermann K, Nielsen P, Tørring DB, Larsen MM, Holmer M (2014) Mussels as a tool for mitigation of nutrients in the marine environment. Mar Pollut Bull 82:137-143

> Peterson BJ, Heck KL Jr (2001) Positive interactions between suspension-feeding bivalves and seagrass - a facultative mutualism. Mar Ecol Prog Ser 213:143-155

Prins T, Escaravage V (2005) Can bivalve suspensionfeeders affect pelagic food web structure? In: Dame RF, Olenin S (eds) The comparative roles of suspensionfeeders in ecosystems. NATO Science Series IV: Earth and Environmental Series, Vol 47, p 31-51

Prins TC, Escaravage V, Smaal AC, Peters JCH (1995) Nutrient cycling and phytoplankton dynamics in relation to mussel grazing in a mesocosm experiment. Ophelia 41: 289-315

Rice MA (2001) Environmental impacts of shellfish aquaculture: filter feeding to control eutrophication. In: Halvorson HO (ed) Workshop on aquaculture and the marine environment: a meeting for stakeholders in the Northeast. University of Massachusetts, Boston, MA, p 1-11
Rodhouse PG, Roden CM, Hensey MP, Ryan TH (1984) Resource allocation in Mytilus edulis on the shore and in suspended culture. Mar Biol 84:27-34

Rosland R, Bacher C, Strand Ø, Aure J, Strohmeier T (2011) Modelling growth variability in longline mussel farms as a function of stocking density and farm design. J Sea Res 66:318-330

Saurel C, Petersen JK, Wiles PJ, Kaiser MJ (2013) Turbulent mixing limits mussel feeding: direct estimates of feeding rate and vertical diffusivity. Mar Ecol Prog Ser 485: 105-121

Sepúlveda J, Pantoja S, Hughen K, Lange C and others (2005) Fluctuations in export productivity over the last century from sediments of a southern Chilean fjord $\left(44^{\circ} \mathrm{S}\right)$. Estuar Coast Shelf Sci 65:587-600

Skinner MA, Courtenay SC, McKindsey CW, Carver CE, Mallet AL (2014) Experimental determination of the effects of light limitation from suspended bag oyster (Crassostrea virginica) aquaculture on the structure and photosynthesis of eelgrass (Zostera marina). J Exp Mar Biol Ecol 459:169-180

Smaal AC (1991) The ecology and cultivation of mussels: new advances. Aquaculture 94:245-261

Smaal AC, Stralen MV, Schuiling E (2001) The interaction between shellfish culture and ecosystem processes. Can J Fish Aquat Sci 58:991-1002

Smaal AC, Schellekens T, van Stralen MR, Kromkamp JC (2013) Decrease of the carrying capacity of the Oosterschelde estuary (SW Delta, NL) for bivalve filter feeders due to overgrazing? Aquaculture 404-405:28-34

Smith P, Martino D, Cai Z, Gwary D and others (2008) Greenhouse gas mitigation in agriculture. Philos Trans R Soc Lond B Biol Sci 363:789-813

Steffani CN, Branch GM (2003) Growth rate, condition, and shell shape of Mytilus galloprovincialis: responses to wave exposure. Mar Ecol Prog Ser 246:197-209

Strohmeier T, Strand Ø, Alunno-Bruscia M, Duinker A, Cranford PJ (2012) Variability in particle retention efficiency by the mussel Mytilus edulis. J Exp Mar Biol Ecol 412:96-102

Tang Q, Zhang J, Fang J (2011) Shellfish and seaweed mariculture increase atmospheric $\mathrm{CO}_{2}$ absorption by coastal ecosystems. Mar Ecol Prog Ser 424:97-104

Trottet A, Roy S, Tamigneaux E, Lovejoy C, Tremblay R (2008) Influence of suspended mussel farming on planktonic communities in Grande-Entrée Lagoon, Magdalen Islands (Québec, Canada). Aquaculture 276:91-102

UN (2013) World population prospects: the 2012 revision population database. http://esa.un.org/wpp (accessed on 13 June 2013)

- Vaquer A, Troussellier M, Courties C, Bibent B (1996) Standing stock and dynamics of picophytoplankton in the Thau Lagoon (northwest Mediterranean coast). Limnol Oceanogr 41:1821-1828

> Waldbusser GG, Powell EN, Mann R (2013) Ecosystem effects of shell aggregations and cycling in coastal waters: an example of Chesapeake Bay oyster reefs. Ecology 94:895-903

Winberg GG (1960) Rate of metabolism and food requirements of fishes. J Fish Res Board Can Transl Ser 194:1-202 